\title{
The Effect of Shading and Leaf Flushing on the Ripening Pattern of Durians
}

\author{
Jingtair Siriphanich ${ }^{1,2 *}$, Anak Pakcharoen ${ }^{1}$, Kiranun Mohpraman' ${ }^{1}$ and Rujira Tisarum ${ }^{1}$ \\ ${ }^{1}$ Department of Horticulture, Faculty of Agriculture at Kamphaeng Saen, Kasetsart University, Nakhon Pathom 73140, Thailand \\ ${ }^{2}$ Postharvest Innovation Center, Commission of Higher Education, Bangkok 10400, Thailand
}

\begin{abstract}
Uneven fruit ripening is often observed in durians (Durio zibethinus Murray), but its cause is unknown. In order to understand the development of this disorder, 'Mon-Thong' durians from leaf flushing and shaded trees were studied. It was found that durians normally accumulated photosynthate and ripened, by converting starch to sugar, unevenly in the direction from the stylar end to the stem end; however, in terms of softening, uneven ripening was found to be non-directional. The fruit from leaf flushing trees was found to have a higher uneven fruit softening score, as well as higher variation in pulp firmness but not soluble solids content, than those harvested from control trees. In addition, fruit from 50\% shaded trees, 99-105 days after full bloom (DAF), was compared to fruit from non-shaded trees. Higher uneven fruit softening was found in durians from shaded trees. When durians were harvested again one week after removal of shading, they had similar ripening characteristics to those from control trees. It was shown that factors that limit fruit development and its maturity positively enhance the non-directional softening pattern. It was also found that treating durians with a high concentration of ethephon could not alleviate this phenomenon.
\end{abstract}

Key Words: durian, leaf flushing, shading, softening, uneven fruit ripening.

\section{Introduction}

Durian is an important economic tropical fruit crop in South-East Asia. The main production areas are in Indonesia, Malaysia, and Thailand. 'Mon-Thong' durian is the most popular cultivar in Thailand. It has an excellent taste, mild odor, thick pulp, and many aborted seeds; however, low quality fruit is often found, including immature and fungal-infected fruit. In addition, uneven fruit ripening is often found in this cultivar. Some parts of the pulp may be unripe, firm, and without taste, while other parts may be overripe, very soft and with an abnormal taste. This disorder could be found even within the same locule (Sapii and Nanthachai, 1994; Subhadrabandhu and Ketsa, 2001).

Sapii and Nanthachai (1994) reported that larger durians and those with thick pulp had a higher uneven fruit ripening incidence than smaller fruit and those with thin pulp. A previous study on the development of 'MonThong' durian revealed that starch accumulation among various locules in a fruit, or even in the same locule or in the pulp around one seed, was not uniform (Siriphanich, 2002). Pakcharoen et al. (2008) reported that 'Mon-Thong' durians harvested earlier, at 106 days

Received; June 22, 2010. Accepted; December 202010.

* Corresponding author (E-mail: agrjts@ku.ac.th). after full bloom (DAF), had a higher incidence of uneven softening than those harvested a week later. In addition, durians harvested from trees that were shaded for 3 weeks before harvesting ripened unevenly.

The uneven fruit ripening pattern can be divided into 2 groups. The first is directional uneven fruit ripening, which is normal and can be found in most fruits. For example, papaya begins to ripen from the blossom to the stem end (Kader, 2002). Pineapple starts from the base and proceeds to the crown (Bartholomew et al., 2003). The other pattern is non-directional. This is usually found in fruit subjected to abnormal growing conditions, such as tomatoes grown under high temperature (Mulholland et al., 2003) or with potassium deficiency (Windsor, 1973), and strawberries in which the achene fails to develop at the same time due to an unsuitable environment (Given et al., 1988). In addition, non-directional uneven ripening was observed in fruit stored under unfavorable condition such as mangoes stored at chilling temperature (Lederman et al., 1997).

Durians are generally observed to begin ripening from the stylar end and progress to the stem end; however, no numeric data are available to support this statement. In this study, we characterize the ripening pattern of typical durians. In uneven ripening durians, it is possible that these fruit are harvested at a chronologically mature stage, but are not physiologically mature. There may be 
pre-harvest factors that limiting fruit growth and maturation. As a result, these fruit may not be evenly mature at harvest. Some parts of the fruit may develop and become more mature than others, as evidenced by the non-uniform accumulation of starch in the pulp of 'Mon-Thong' durians (Siriphanich, 2002). Durian trees normally have one or two new leaf flushes after harvest during the rainy season. During the dry season when the fruit are developing, however, flushing can occur if there is rain and this could affect fruit development by competing for photosynthate, resulting in delayed maturation of the fruit. Similarly, shading of plant limits photosynthesis; hence, shading could restrict the developing fruit and consequently their maturation. Fruit that are harvested at an immature stage are known to have less capacity to produce ethylene and need longer exposure to exogenous ethylene to ripen, e.g. tomatoes (McGlasson et al., 1975) and may ripen unevenly. For this reason, leaf flushing during fruit maturation was tested whether it is another factor that influences durian fruit maturity, resulting in uneven fruit ripening. In our previous shading study (Pakcharoen et al., 2008), durian trees were shaded for 3 weeks. This shading duration was rather long and might not occur under natural conditions. One-week shading, representing a cloudy period that often occurs during the durian harvesting season, was tested in this study to show whether short-term shading could also be a factor influencing the durian ripening pattern. Finally, it was reported that ethylene treatment could reduce uneven fruit ripening in mangoes (Pal, 1998) and papayas (An and Paull, 1990). The application of ethephon to 'Mon-Thong' durians was performed to determine whether this uneven ripening phenomenon is merely the lack of durians' ability to produce ethylene.

\section{Materials and Methods}

\section{Effect of leaf flushing}

A comparative study between fruit from non-flushing and leaf flushing trees was conducted in a 2-way nested experiment in a completely randomized design. Fifteenyear-old 'Mon-Thong' durian trees from an orchard in Chanthaburi province in eastern Thailand were used in this experiment. They were of uniform size, having a $9 \mathrm{~m}$ diameter canopy, with each bearing about 50 fruit per tree. Six trees, growing in the same block with uniform soil type and within $30 \mathrm{~m}$ radius of each other, were sampled. Three trees had no new leaf flush and another three had new leaf flushes, starting bud break at $72 \mathrm{DAF}$ and becoming hardened at $114 \mathrm{DAF}$, covering the whole canopy. Six durians were harvested at 100 DAF from each tree. Eighteen fruits were obtained for both treatments. The fruit was kept at room temperature $\left(27 \pm 2^{\circ} \mathrm{C}, 86 \pm 4 \% \mathrm{RH}\right)$ and allowed to ripen, as determined daily from their hollow sound after knocking and a slight durian odor. The fruit was then split open. Three locules from each fruit were sampled for quality evaluation.
Objective evaluations, including firmness, soluble solids, and dry matter were determined from samples taken randomly from the top, middle, and bottom of each locule. One position was used as one replication. Firmness was determined with a fruit firmness tester (Effegi, Alfonsine, Italy), using an $8 \mathrm{~mm}$ diameter plunger head. For soluble solids content, $3 \mathrm{~g}$ pulp from each position was homogenized with $9 \mathrm{~mL}$ distilled water. The homogenate was then centrifuged at $6,000 \times \mathrm{g}$ for $15 \mathrm{~min}$. The supernatant was used for soluble solids determination using a hand refractometer (N30, Atago, Japan). The refractometer reading was multiplied by 4 for actual soluble solids content. Dry matter was determined by taking a $10 \mathrm{~g}$ pulp sample from each of the 3 positions. The samples were chopped into small pieces and dried at $65^{\circ} \mathrm{C}$ in a forced-air oven for 6 days to constant weight, and then weighed for dry matter calculation.

Since the objective methods could not directly measure unevenness, a subjective evaluation of uneven durian softening was also performed. This was performed by hand in two steps: First, the entire pulp surface of each locule was touched lightly to determine pulp firmness from the top fifth to the bottom fifth of the locule. Firmness scores $(5=$ hard, $4=$ firm, $3=$ begining to soften, $2=$ soft, and $1=$ watery soft) were then recorded for each of the 5 portions of the locule. Second, uneven softening scores of 1-4 were then given to each locule. Score 1 was given if there was only one level or uniform pulp firmness (no matter whether it was soft or firm) and scores of 2, 3, and 4 were given when there were 2,3 , and 4 levels of pulp firmness in the locule, respectively. A durian locule with 5 levels of pulp firmness was not found. Only uneven softening scores were used for statistical analysis. One locule was used as one replication.

\section{Effect of shading}

Eight 10-year-old 'Mon-Thong' durian trees of similar size ( $7 \mathrm{~m}$ diameter canopy), bearing about 40 fruit, from an orchard in Chantaburi province, were used. During a period of one week from 99 to 105 DAF (counting from when the trees were in full bloom), when the fruits had ceased growth and were near the end of the food-accumulating stage, four trees were covered with black 'saran' net $(50 \%$ shading as specified by the manufacturer) on all sides over the $8 \times 8 \times 8 \mathrm{~m}$ scaffolds around each tree, leaving only one meter of space above ground. The other four trees were left uncovered and used as the control. Maximum temperature and minimum relative humidity in the canopy of shaded trees were found to be about $1.6^{\circ} \mathrm{C}$ lower and $10 \%$ higher than in non-shaded trees, respectively. Minimum temperature and maximum relative humidity in the canopy of both types of trees were similar. After removal of the 'saran' net, 10 fruits from each tree were immediately harvested at 106 DAF. A week later another 10 fruits were 
harvested at $113 \mathrm{DAF}$. The fruit were kept at room temperature $\left(27 \pm 2^{\circ} \mathrm{C}, 86 \pm 4 \% \mathrm{RH}\right)$, allowed to ripen and were evaluated as described in the first experiment.

\section{Effect of postharvest application of ethephon}

Fifty-six uniform size fruit of 'Mon-Thong' durian were harvested at 106 and 113 DAF from 4 uniform 7year-old trees in an orchard in Chanthaburi. Half of the fruits had about $0.3 \mathrm{~mL}$ of $48 \%$ (active ingredient) ethephon applied using a paint brush to the cut surface of the fruit stem within $5 \mathrm{~h}$ after harvest. The other half had water applied (control). All fruit were kept at room temperature $\left(27 \pm 2^{\circ} \mathrm{C}, 86 \pm 4 \% \mathrm{RH}\right)$, allowed to ripen and were evaluated in the same manner as in the previous experiments.

\section{Statistical analysis}

In experiment 1, two-way nested analysis of variance was used to analyze variance and the treatment means of all objective parameters. To compare the objective parameters between the 3 positions, two-way analysis of variance and Duncan's multiple range test were performed. In experiment 2 and 3, three-way analysis of variance was performed for all objective parameters. The subjective uneven softening scores were statistically compared between treatments by the Wilcoxon rank sum test. $P$-values greater than 0.05 were regarded as nonsignificant. SAS version 8 software was used for all analysis.

\section{Results}

\section{Effect of leaf flushing on uneven fruit ripening}

From the objective evaluation, durians from leaf flushing trees had lower pulp dry matter and soluble solids content than those found in non-flushing trees
(Table 1); however, firmness was not different between the two types of trees. Subjectively, it was found that durians from leaf flushing trees had a higher uneven fruit softening score than those from normal trees.

Variance comparison between the two types of durian trees (Table 1) revealed that durians from leaf flushing trees had significantly higher variance of dry matter and firmness than those from non-flushing trees. The higher total variance of fruit firmness conformed to the higher uneven softening score. On the other hand, there was no difference in the variance of the soluble solids contents. It should also be noted that the variance was relatively high for firmness as compared to that of dry matter and soluble solids content.

When comparing the three positions of durian pulp from both non-flushing and leaf flushing trees, it was found that dry matter was not different (Table 1); however, soluble solids content at the stem end was lower than that at the mid-position and stylar end. On the other hand, the firmness was lowest in the midposition. In this experiment, no interaction was found between the treatment and the locule position.

\section{Effect of shading on uneven fruit ripening}

Fifty percent shading for one week between 99 to 106 DAF resulted in about 3\% lower dry matter of durian as compared to that from non-shaded trees (Table 2). This effect was carried on even after durian trees were returned to normal light conditions for another week and harvested at 113 DAF. Shading effects were also found on soluble solids content and firmness. The subjective evaluation of uneven ripening showed that shading causes a higher uneven softening score. When durian trees were returned to normal light conditions and harvested at $113 \mathrm{DAF}$, the uneven softening score

Table 1. Means and variance comparison of pulp dry matter, soluble solids content, and firmness and mean comparison of the uneven ripening score of Mon-Thong durians harvested from non-flushing and flushing trees (A). Average dry matter, soluble solids content, and firmness of durian pulp at 3 durian locule positions (B).

\begin{tabular}{|c|c|c|c|c|c|c|}
\hline \multicolumn{7}{|c|}{ A. Mean and variance comparison } \\
\hline \multirow{2}{*}{ Parameters } & \multicolumn{2}{|c|}{ Means } & \multirow{2}{*}{$P$-value ${ }^{\mathrm{z}}$} & \multicolumn{2}{|c|}{ Variance } & \multirow{2}{*}{$P$-value } \\
\hline & Non Flushing & Leaf Flushing & & Non Flushing & Leaf Flushing & \\
\hline \multicolumn{7}{|l|}{ Objectives } \\
\hline Dry matter $(\%)$ & 29.8 & 27.8 & $* *$ & 17.75 & 36.29 & $* *$ \\
\hline Soluble solids (\%) & 23.3 & 21.7 & $* *$ & 14.41 & 17.80 & NS \\
\hline Firmness $\left(\mathrm{N} / \mathrm{cm}^{2}\right)$ & 8.5 & 9.2 & NS & 30.82 & 71.50 & $* *$ \\
\hline \multicolumn{7}{|l|}{ Subjective } \\
\hline Uneven ripening score & 2.54 & 3.09 & $* *$ & - & - & \\
\hline \multicolumn{7}{|c|}{ B. Average dry mater, soluble solids content, and firmness } \\
\hline \multirow{2}{*}{ Parameters } & \multicolumn{3}{|c|}{ Pulp position } & \multirow{2}{*}{ C.V. (\%) } & \multirow{2}{*}{$P$-value } & \multirow{2}{*}{$\begin{array}{l}\text { Interaction with } \\
\text { treatment }\end{array}$} \\
\hline & Stem end & Mid-position & Stylar end & & & \\
\hline Dry matter (\%) & 28.6 & 29.2 & 28.6 & 16.19 & NS & NS \\
\hline $\operatorname{SSC}(\%)$ & $21.8 \mathrm{~b}$ & $23.0 \mathrm{a}$ & $22.6 a b$ & 16.96 & $*$ & NS \\
\hline Firmness $\left(\mathrm{N} / \mathrm{cm}^{2}\right)$ & $9.0 \mathrm{ab}$ & $8.1 \mathrm{~b}$ & $9.4 \mathrm{a}$ & 78.21 & $* *$ & NS \\
\hline
\end{tabular}

${ }^{\mathrm{z}}$ NS: non-significant, ${ }^{*}$ significance at $P=0.05,{ }^{* *}$ significance at $P=0.01$ by Duncan multiple range test. Uneven ripening score was analyzed by Wilcoxon's rank sum test. 
Table 2. Means and variance comparison of pulp dry matter, soluble solids content, and firmness and mean comparison of uneven ripening score of Mon-Thong durians, harvested at 106 and 113 DAF, from non-shaded and 1-week-shaded trees, and the average dry matter, soluble solids content, and firmness of durian pulp at 3 durian locule positions.

\begin{tabular}{|c|c|c|c|c|c|c|c|c|}
\hline \multirow{2}{*}{ Objective Parameters } & \multicolumn{2}{|c|}{ Treatment (A) } & \multirow{2}{*}{$P$-value ${ }^{\mathrm{z}}$} & & \multicolumn{2}{|c|}{ Variance } & \multirow{2}{*}{$P$-value } & \\
\hline & Non-shaded & Shaded & & & Non-shaded & Shaded & & \\
\hline Dry mater $(\%)$ & 34.27 & 31.45 & $* *$ & & 20.75 & 20.65 & NS & \\
\hline Soluble solids $(\%)$ & 26.23 & 24.84 & $* *$ & & 7.51 & 8.66 & $* *$ & \\
\hline \multirow[t]{3}{*}{ Firmness $\left(\mathrm{N} / \mathrm{cm}^{2}\right)$} & 8.49 & 9.44 & $* *$ & & 6.34 & 12.13 & $* *$ & \\
\hline & \multicolumn{2}{|c|}{ Harvest Time (B) } & \multirow{2}{*}{$P$-value } & & \multicolumn{2}{|c|}{ Variance } & $P_{\text {Nolu }}$ & \\
\hline & $106 \mathrm{DAF}$ & $113 \mathrm{DAF}$ & & & $106 \mathrm{DAF}$ & $113 \mathrm{DAF}$ & $P$-vaiue & \\
\hline Dry mater $(\%)$ & 26.25 & 36.47 & $* *$ & & 11.09 & 8.20 & $* *$ & \\
\hline Soluble solids $(\%)$ & 23.81 & 27.26 & $* *$ & & 5.61 & 5.57 & NS & \\
\hline \multirow{3}{*}{ Firmness $\left(\mathrm{N} / \mathrm{cm}^{2}\right)$} & 9.52 & 8.41 & $* *$ & & 12.87 & 5.44 & $* *$ & \\
\hline & \multicolumn{3}{|c|}{ Pulp position $(\mathrm{C})$} & \multirow{2}{*}{$P$-value } & \multicolumn{3}{|c|}{ Variance } & \multirow{2}{*}{$P$-value } \\
\hline & Stem end & Mid-position & Stylar end & & Stem end & Mid-position & Stylar end & \\
\hline Dry mater (\%) & $31.77 \mathrm{c}$ & $33.17 \mathrm{~b}$ & $33.65 \mathrm{a}$ & $* *$ & 22.85 & 22.31 & 21.00 & NS \\
\hline Soluble solids $(\%)$ & $24.33 \mathrm{c}$ & $25.85 b$ & $26.42 \mathrm{a}$ & $* *$ & 7.62 & 7.46 & 8.30 & $*$ \\
\hline Firmness $\left(\mathrm{N} / \mathrm{cm}^{2}\right)$ & 8.93 & 8.76 & 9.2 & NS & 10.98 & 7.57 & 9.76 & $* *$ \\
\hline Interaction & & Dry matter & & Soluble solids & & Firmness & & \\
\hline $\mathrm{A} \times \mathrm{B}$ & & NS & & $*$ & & $* *$ & & \\
\hline $\mathrm{A} \times \mathrm{C}$ & & NS & & $\mathrm{NS}$ & & NS & & \\
\hline $\mathrm{B} \times \mathrm{C}$ & & $*$ & & NS & & NS & & \\
\hline $\mathrm{A} \times \mathrm{B} \times \mathrm{C}$ & & NS & & NS & & NS & & \\
\hline C.V. $(\%)$ & & 8.07 & & 8.14 & & 33.10 & & \\
\hline \multirow{2}{*}{ Subjective Parameter } & \multicolumn{2}{|c|}{ Treatment } & \multirow{2}{*}{$P$-value } & & \multicolumn{2}{|c|}{ Harvest Time } & $P$-value & \\
\hline & Non-shaded & Shaded & & & $106 \mathrm{DAF}$ & 113 DAF & $P$-value & \\
\hline Uneven ripening score & 2.30 & 2.36 & $*$ & & 2.60 & 2.05 & $* *$ & \\
\hline
\end{tabular}

${ }^{\mathrm{z}} \mathrm{NS}$ : non-significant, ${ }^{*}$ significance at $P=0.05, * *$ significance at $P=0.01$ by Duncan multiple range test. Uneven ripening score was analyzed by Wilcoxon's rank sum test.

became significantly lower.

When variances were compared between treatments it was found that shading resulted in a higher variance of the soluble solids content and pulp firmness (Table 2). No difference in variance was found for dry matter. Once durian trees were returned to normal light conditions and harvested at $113 \mathrm{DAF}$, the variances became lower, particularly for firmness.

Both non-shaded and shaded trees were found to have the lowest dry matter and soluble solids content at the stem end, and the highest at the stylar end; however, firmness was not different among the three positions (Table 2). An interaction was found between the harvested date and the locule position in dry matter content, indicating more mature pulp at the stylar end. Interactions between the shading treatment and harvest date were found for soluble solids content and firmness, indicating the higher influence of shading on younger fruit.

\section{Effect of ethephon on uneven fruit ripening}

Dry matter evaluation of durian pulp showed that durian maturity was comparable between the two treatments (Table 3), averaging at about 36\%. Pulp firmness of durians treated with ethephon was lower than the control, indicating the effectiveness of ethephon at enhancing durian ripening. The interaction found between ethephon treatment and the harvest date for soluble solids content and firmness indicated that more mature durians responded better to ethephon. Interestingly, soluble solids content in treated fruit was significantly lower than the control.

Variance comparison between treatments (Table 3) revealed that ethephon treatment reduced the variance of the dry matter and soluble solids content, but did not reduce the variance of pulp firmness. The ineffectiveness of ethephon at reducing the variance of pulp firmness was found to be in agreement with its ineffectiveness at reducing the uneven fruit softening score, whereas ethephon treatment slightly enhanced the uneven softening score.

Durians harvested on 113 DAF were more mature than those harvested on $106 \mathrm{DAF}$ as evidented by the $6 \%$ higher dry matter, $3 \%$ higher soluble solids content, and $1 \mathrm{~N} / \mathrm{cm}^{2}$ lower firmness. The interaction between the harvest date and pulp position on soluble solids content indicated that more mature fruit had more starch to convert to sugar. Variances of all three parameters 
Table 3. Means and variance comparison of pulp dry matter, soluble solids content, and firmness and mean comparison of uneven ripening score of durians, harvested at 106 and $113 \mathrm{DAF}$, treated or not treated with ethephon, and the average dry matter, soluble solids content, and firmness of durian pulp at 3 durian locule positions.

\begin{tabular}{|c|c|c|c|c|c|c|c|c|}
\hline \multirow{2}{*}{ Objective Parameters } & \multicolumn{2}{|c|}{ Treatment (A) } & \multirow{2}{*}{$P$-value ${ }^{\mathrm{z}}$} & & \multicolumn{2}{|c|}{ Variance } & \multirow{2}{*}{$P$-value } & \\
\hline & Non-ethylene & Ethylene & & & Non-ethylene & Ethylene & & \\
\hline Dry mater $(\%)$ & 35.71 & 36.05 & NS & & 20.88 & 17.47 & $* *$ & \\
\hline Soluble solids (\%) & 27.77 & 26.68 & $* *$ & & 10.77 & 8.58 & $* *$ & \\
\hline \multirow[t]{3}{*}{ Firmness $\left(\mathrm{N} / \mathrm{cm}^{2}\right)$} & 8.89 & 7.04 & $* *$ & & 8.51 & 7.99 & NS & \\
\hline & \multicolumn{2}{|c|}{ Harvest Time (B) } & \multirow{2}{*}{$P$-value } & & \multicolumn{2}{|c|}{ Variance } & $P$ & \\
\hline & $106 \mathrm{DAF}$ & $113 \mathrm{DAF}$ & & & $106 \mathrm{DAF}$ & $113 \mathrm{DAF}$ & $P$-value & \\
\hline Dry mater $(\%)$ & 32.63 & 39.13 & $* *$ & & 11.36 & 5.87 & $* *$ & \\
\hline Soluble solids (\%) & 25.50 & 28.94 & $* *$ & & 8.52 & 5.51 & $* *$ & \\
\hline \multirow[t]{3}{*}{ Firmness $\left(\mathrm{N} / \mathrm{cm}^{2}\right)$} & 8.51 & 7.42 & $* *$ & & 11.35 & 6.27 & $* *$ & \\
\hline & \multicolumn{3}{|c|}{ Pulp position (C) } & \multirow{2}{*}{$P$-value } & \multicolumn{3}{|c|}{ Variance } & \multirow{2}{*}{$P$-value } \\
\hline & Stem end & Mid position & Stylar end & & Stem end & Mid position & Stylar end & \\
\hline Dry mater (\%) & $34.72 b$ & $36.26 \mathrm{a}$ & $36.67 \mathrm{a}$ & $* *$ & 20.32 & 18.32 & 16.91 & $* *$ \\
\hline Soluble solids (\%) & $25.96 \mathrm{c}$ & $27.63 b$ & $28.08 \mathrm{a}$ & $* *$ & 10.64 & 8.31 & 8.51 & $* *$ \\
\hline Firmness $\left(\mathrm{N} / \mathrm{cm}^{2}\right)$ & $7.74 b$ & $7.89 \mathrm{ab}$ & $8.26 \mathrm{a}$ & $*$ & 12.29 & 8.08 & 6.83 & $* *$ \\
\hline Interaction & & Dry matter & & Soluble solids & & Firmness & & \\
\hline $\mathrm{A} \times \mathrm{B}$ & & NS & & $*$ & & $*$ & & \\
\hline $\mathrm{A} \times \mathrm{C}$ & & NS & & NS & & $* *$ & & \\
\hline $\mathrm{B} \times \mathrm{C}$ & & NS & & $* *$ & & NS & & \\
\hline $\mathrm{A} \times \mathrm{B} \times \mathrm{C}$ & & NS & & NS & & NS & & \\
\hline C.V. $(\%)$ & & 7.84 & & 8.83 & & 34.97 & & \\
\hline \multirow{2}{*}{ Subjective Parameter } & \multicolumn{2}{|c|}{ Treatment } & \multirow{2}{*}{$P$-value } & & \multicolumn{2}{|c|}{ Harvest Time } & \multirow{2}{*}{$P$-value } & \\
\hline & Non-ethylene & Ethylene & & & $106 \mathrm{DAF}$ & $113 \mathrm{AF}$ & & \\
\hline Uneven ripening score & 2.29 & 2.35 & $*$ & & 2.52 & 2.12 & $* *$ & \\
\hline
\end{tabular}

were higher in less mature 106 DAF durians.

The highest dry matter, soluble solids content, and firmness were found at the stylar end followed by the mid-portion and the stem end; however, highest variances were found at the stem end followed by the mid-position and stylar end in most cases, indicating more variation in durian pulp maturation and ripening at the stem end. The interaction between ethephon treatment and the position of the locule for firmness indicated that ethephon given through the cut surface of the stem influenced the softening process at the stem end earlier than at the stylar end.

\section{Discussion}

By observing dry matter contents among the three positions, we found that in two out of the three experiments the dry matter was highest at the stylar end and lowest at the stem end. This indicates that durians accumulate food in the pulp at the stylar end first and proceed to the stem end. A similar finding was found for the soluble solids content, indicating that durians ripen, by converting starch to sugar, first at the stylar end and proceed to the stem end; however, there was no clear pattern of softening among the three positions. In the first experiment, the firmness was highest at the stylar end and lowest at the mid-position. In the second experiment, there was no different in firmness among the three positions. In the third experiment, the firmness was highest at the stylar end and lowest at the stem end. In addition, we did not observe a soft pulp area at any specific position within a locule. The soft pulp area could be observed at the stem end in one case, at the midposition or the stylar end in another, or at the stem end together with the stylar end, etc. With this information, it is suggested that the typical ripening pattern of durians is uneven. From the view of soluble solids content or starch converting to sugar, uneven ripening is directional from the stylar end to the stem end; however, from the view of firmness, uneven ripening or softening is nondirectional.

The leaf flushing and shading experiments showed that the two factors brought about a reduction in the dry matter content of durian pulp. Comparable findings were reported previously. Leaf flushing during early durian development, 20-25 days from anthesis, may reduce the number of fruitlets and increase the percentage of deformed fruit (Salakpetch, 1996). Leaf flushing during fruit development may cause competition for photosynthesis products (carbohydrates) between developing fruits and young leaves, resulting in less carbohydrate 
available for fruit development than in fruit from trees where there was no leaf flushing during fruit development. An example of competition for photosynthate during leaf flushing was reported in seedlings of red oak (Dickson et al., 2000). 'Mon-thong' durians develop slowly during the first 14 days followed by a rapid growth phase until 84 DAF when cell division ceases. The pulp begins to develop at 35 DAF and grows rapidly to $84 \mathrm{DAF}$ before leveling off. Fruit maturation, including sugar, starch, and lipid accumulation, takes place after the pulp growth slows down and reaches full maturity at around 120 DAF (Koksungnoen and Siriphanich, 2008). Leaf flushing during this maturation process could lead to fruit having some parts that have developed well to maturity with full carbohydrate and lipid accumulation and attendant ability to ripen, while other parts are still immature. In other words, the fruit mature unevenly. Once harvested, the fruit are likely to ripen unevenly. A similar explanation could be made for fruit harvested from shaded plants. In addition, when shading was removed and the fruit were allowed to develop for a further week, the uneven softening score and the variance of firmness were reduced. This additional finding supported the role of photosynthate competition in the maturation of durians and their subsequence ripening pattern.

Under natural conditions, a cloudy or rainy period of one week during the durian harvesting season is not uncommon. This weather condition resembled the shading effect and could lead to fruit with a higher degree of uneven ripening. It is therefore recommended that if there is rain or cloud during the early harvesting season, harvesting should be delayed in order to obtain fruit with less uneven softening.

In the case of leaf flushing, which occasionally occurs after heavy rainfall during fruit maturation, it is recommended that durian farmers remove new leaves as soon as possible. Spraying the durian canopy with a low concentration of ethephon solution to induce young leaf abscission is worth investigation.

Although leaf flushing and shading brought about a reduction in the dry matter content of durian pulp, the two factors did not always lead to an increase in the variance of dry matter. Correspondingly the two factors brought about a reduction in soluble solids content, but only shading increased its variance. Hence, leaf flushing and shading did not clearly influence the directional ripening pattern in terms of starch converting to sugar. On the other hand, leaf flushing and shading brought about only slightly higher durian pulp firmness, but always doubled the variance of firmness and increased the uneven softening score. Hence, the two factors clearly enhanced the non-directional ripening pattern in terms of softening.

The uneven fruit ripening phenomenon might be explained by the fact that less mature durians produced less ethylene than more mature fruit (Tongdee et al.,
1990). In addition, 'Mon-Thong' durians produce much less ethylene than other durian cultivars (Siriphanich et al., 1994). Furthermore, most ethylene produced in durians came from the husk rather than the pulp (Bunjerm and Siriphanich, 1991). In our ethephon experiment, the earlier harvested durians had a higher uneven ripening incidence than those harvested later, as observed by the higher uneven softening score and higher variances. This could be explained by the early harvest durians possibly producing a very low level of ethylene and hence could not induce even ripening. With ethephon treatment, durian ripening was enhanced as evidenced by the lower pulp firmness and uneven softening, both in terms of the uneven softening score and variance of the firmness. The result was different from those reported in other commodities. For example, the application of ethephon to mangoes reduced the variation in firmness among top, middle, and bottom parts of the fruit (Pal, 1998). In papaya, after exposure to exogenous ethylene, the coefficient of variance of peel color was about 6 times lower (An and Paull, 1990). From our results, it is suggested that uneven fruit ripening in durians was not simply the lack of their ability to produce ethylene. One possibility is that these durians might have an uneven distribution of ethylene receptor in different positions of the pulp. Control of the timing of fruit ripening by the degradation of ethylene receptor proteins, which negatively regulate ethylene signal transduction, have been reported in tomato (Kevany et al., 2007). It is possible that immature parts of durian pulp contain a high level of ethylene receptor which suppresses the ripening process in those parts, while the fully mature parts contain a low level of receptors. The actual factor limiting the ability of durian pulp to ripen, particularly softening, should be further investigated.

From these results, it can be concluded that durians naturally ripen unevenly in the direction from the stylar end to the stem end in terms of starch converting to sugars; however, softening of the pulp is non-directional. Leaf flushing and shading enhance only non-directional uneven softening. Ethylene was not found to be a limiting factor for this uneven-softening phenomenon. Also, it can be reasoned that other factors, such as pathogens, insects, drought, flood, strong winds, and excessive fruit set, could limit fruit maturation and lead to nondirectional uneven softening disorders in durians.

\section{Acknowledgements}

The authors would like to thank Kasetsart University Research and Development Institute and Postharvest Technology Innovation Center, PERDO, Commission of Higher Education for supporting this research, and to Helen Brady for her help in preparing the manuscript.

\section{Literature Cited}

An, J. and R. E. Paull. 1990. Storage temperature and ethylene influence on ripening of papaya fruit. J. Amer. Soc. Hort. 
Sci. 115: 949-953.

Bartholomew, D. P., E. Malézieux, G. M. Sanewski and E. Sinclair. 2003. Inflorescence and fruit development and yield. p. 167222. In: D. P. Bartholomew, R. E. Paull and K. G. Rohrbach (eds.). The pineapple: botany production, and uses. CAB International, Oxon.

Bunjerm, P. and J. Siriphanich. 1991. Postharvest physiology of durian pulp and husk. Kasetsart J. 25: 119-125.

Dickson, R. E., P. T. Tomlinson and J. G. Isebrands. 2000. Partitioning of current photosynthate to different chemical fractions in leaves, stems, and roots of northern red oak seedlings during episodic growth. J. Forest Res. 30: 13081317.

Given, N. K., M. A. Venis and D. Gierson. 1988. Hormonal regulation of ripening in the strawberry, a non-climacteric fruit. Planta 174: 402-406.

Kader, A. A. 2002. Postharvest technology of hortultural crops, $3^{\text {rd }}$ ed. University of California Agriculture and Natural Resources, California.

Kevany, B. M., D. M. Tieman, M. G. Taylor, V. Dal Cin and H. J. Klee. 2007. Ethylene receptor degradation controls the timing of ripening in tomato fruit. Plant J. 51: 458-467.

Koksungnoen, O. and J. Siriphanich. 2008. Anatomical changes during fruit development of durian cvs. 'Kradum' and 'Monthong'. Agricultural Sci. J. 39: 35-44 (In Thai with English abstract).

Lederman, I. E., G. Zuaberman, A. Weksle, I. Rot and Y. Fuchs. 1997. Ethylene forming capacity during cold storage and chilling injury development in 'Keitt' mango fruit. Postharvest Biol. Technol. 10: 107-112.

McGlasson, W. B., H. C. Dostal and E. C. Tigchelaar. 1975. Comparison of propylene-induced responses of immature fruit of normal and rin mutant tomatoes. Plant Physiol. 55:
$218-222$.

Mulholland, B. J., R. N. Edmondson, M. Fussell, J. Basham and L. C. Ho. 2003. Effect of high temperature on tomato summer fruit quality. J. Hort. Sci. Biotech. 78: 365-374.

Pakcharoen, A., R. Tisarum and J. Siriphanich. 2008. Maturity stage influences pulp softening in 'Mon-thong' durian during ripening. Agric. Sci. J. 39(3S): 90-93 (In Thai with English abstract).

Pal, R. K. 1998. Ripening and rheological properties of mango as influenced by ethrel and calcium carbide. J. Food Sci. Technol. 35: 358-360.

Salakpetch, S. 1996. Physiology of durian production. Tropical fruit production course notes, 10-12 December 1996, Chanthaburi Horticultural Research Center, Chanthaburi, Thailand: 12 (In Thai with English abstract).

Sapii, A. T. and S. Nanthachai. 1994. Physiological disorders in durian. p. 58-61. In: S. Nanthachai (ed.). Durian: fruit development, postharvest physiology and marketing in ASEAN. ASEAN Food Handling Bureau, Kuala Lumpur.

Siriphanich, J. 2002. Postharvest physiology of tropical fruit. Acta Hort. 575: 623-629.

Siriphanich, J., A. Hassan, M. Kosittrakun and M. C. C. Lizada. 1994. Physiology. p. 48-57. In: S. Nanthachai (ed.). Durian: fruit development, postharvest physiology and marketing in ASEAN. ASEAN Food Handling Bureau, Kuala Lumpur.

Subhadrabandhu, S. and S. Ketsa. 2001. Durian: king of tropical fruit. Daphne Brasell Associates Ltd., Wellington.

Tongdee, S. C., A. Suwangul and S. Neamprem. 1990. Durian fruit ripening and the effect of various maturity stage at harvest and atmospheric gases. Acta Hort. 269: 323-334.

Windsor, C. W. 1973. Nutrition. p. 35-42. In: H. G. Kingman (ed.). The UK tomato manual. Grower Books, London. 